\title{
Calling from distance: attraction of soil bacteria by plant root volatiles
}

\author{
Kristin Schulz-Bohm $^{1} \cdot$ Saskia Gerards ${ }^{1} \cdot$ Maria Hundscheid ${ }^{1} \cdot$ Jasper Melenhorst ${ }^{1} \cdot$ Wietse de Boer $^{1,2}$. \\ Paolina Garbeva ${ }^{1}$
}

Received: 6 July 2017 / Revised: 25 November 2017 / Accepted: 28 November 2017 / Published online: 22 January 2018

(c) International Society for Microbial Ecology 2018

\begin{abstract}
Plants release a wide set of secondary metabolites including volatile organic compounds (VOCs). Many of those compounds are considered to function as defense against herbivory, pests, and pathogens. However, little knowledge exists about the role of belowground plant VOCs for attracting beneficial soil microorganisms. We developed an olfactometer system to test the attraction of soil bacteria by VOCs emitted by Carex arenaria roots. Moreover, we tested whether infection of $C$. arenaria with the fungal pathogen Fusarium culmorum modifies the VOCs profile and bacterial attraction. The results revealed that migration of distant bacteria in soil towards roots can be stimulated by plant VOCs. Upon fungal infection, the blend of root VOCs changed and specific bacteria with antifungal properties were attracted. Tests with various pure VOCs indicated that those compounds can diffuse over long distance but with different diffusion abilities. Overall, this work highlights the importance of plant VOCs in belowground long-distance plant-microbe interactions.
\end{abstract}

\section{Introduction}

Plants are exposed during their entire life to various environmental stresses such as water- and nutrient limitation, pathogenic infections, and herbivory [1]. Interactions with so-called beneficial or plant growth-promoting microbes can relieve stresses [2]. Moreover, plants appear to be able to recruit those beneficial microbes to their roots [3-5]. Plants produce a wide set of secondary metabolites (>200,000 [6] and many of these metabolites play important role in belowground interactions, communication, or recruitment of soil organisms. For instance, legumes produce flavonoids to attract nitrogen-fixing bacteria [7] and

Electronic supplementary material The online version of this article (https://doi.org/10.1038/s41396-017-0035-3) contains supplementary material, which is available to authorized users.

Kristin Schulz-Bohm

K.Schulz-Bohm@nioo.knaw.nl

$\triangle$ Paolina Garbeva

P.Garbeva@nioo.knaw.nl

1 Department of Microbial Ecology, Netherlands Institute of Ecology (NIOO-KNAW), 6700 AB Wageningen, The Netherlands

2 Department of Soil Quality, Wageningen University, 6708 PB Wageningen, The Netherlands maize exudates benzoxazinoids to attract plant growthpromoting bacteria such as Pseudomonas putida [8].

Besides soluble secondary compounds plants release various volatile organic compounds (VOCs) involved in interactions with surrounding soil organisms [9]. It is estimated that VOCs constitute about $1 \%$ of plant secondary metabolites [10]. VOCs are small compounds of low molecular weight, lipophilic character, with high vapor pressure and low boiling points [11-14]. Due to their physicochemical properties, VOCs can easily diffuse through gasand water-filled pores and can, therefore, have a wide effective range in soil. Plant VOCs emitted by roots can function in multiple ways such as antimicrobials, food source, chemo-attractants, or infochemicals [9]. For example, root VOCs like (+)-enantiomers of carvone, limonene, and borneol have been shown to promote bacterial quorum sensing [15]. Furthermore, maize plants release the sesquiterpene (E)- $\beta$-caryophyllene in the rhizosphere when attacked by root feeding beetle larvae, resulting in enhanced attraction of nematodes [16-18]. Interestingly, a very fast emission of sesquiterpenes was also seen to be triggered in maize and other cereal plants upon infestation by Fusarium spp. [19-21] and terpenoid production of potato plants was affected by the inoculation with Phytophthora infestans [22].

However, so far it was not shown if plant VOCs such as terpenes can stimulate the motility of bacteria in the bulk 
soil. Moreover, it is unknown if plants can actively recruit beneficial soil microorganisms by emitting VOCs into the rhizosphere. Recent studies on microbial VOCs demonstrated that bacterial motility can be stimulated by VOCs [23-25], although the applied test systems were rather artificial.

In this study, we tested the hypothesis that VOCs emitted by plants into the rhizosphere can attract soil bacteria from a long distance. To test this hypothesis, a glass olfactometer system was designed to monitor bacterial migration in soil. With this system, we tested (1) if bacteria from a synthetic soil microbial community (originating from the rhizosphere of Carex arenaria) can be attracted to root VOCs emitted by $C$. arenaria and (2) whether there is a difference in the bacterial attraction when the roots of this plant were infected by the soil-borne fungal pathogen Fusarium culmorum. VOCs emitted from infected or non-infected roots were collected, analyzed and, in addition, the diffusion ability of some pure compounds in soil was examined.

The obtained results revealed for the first time that migration of distant soil bacteria outside the rhizosphere can be stimulated by plant root VOCs and that specific bacteria can be attracted by VOCs of plants infected by a fungal pathogen.

\section{Material and methods}

\section{Microorganisms and growth media}

All bacterial strains (Burkholderia sp. AD024, Collimonas pratensis Ter91, Dyella sp. AD056, Janthinobacterium sp. AD080, Paenibacillus sp. AD087, and Pseudomonas sp. AD021) and the fungus F. culmorum $\mathrm{PV}$ were isolated from the rhizosphere of $C$. arenaria (Supplementary Information Appendix S1 and Table S1) and cultured as described before [24, 26, 27]. Asexual spores (conidia) of $F$. culmorum were obtained by growing the fungus on Difco $^{\mathrm{TM}}$ oatmeal agar plates (Becton, Dickinson and Company, France) with $0.2 \mathrm{mg} \mathrm{ml}^{-1}$ streptomycin for 3 weeks at $25^{\circ}$ C. Collected spores were washed twice in sterile demineralized water (demi-water), counted, and kept at $-80{ }^{\circ} \mathrm{C}$ until use.

\section{Plants and cultivation}

C. arenaria seeds were obtained from B and T World Seeds (Aigues-Vives, France). Prior use, the seed were surface sterilized with $70 \%$ ethanol and $4 \mathrm{gl}^{-1}$ sodiumhypoclorite (bleach). In brief, seeds were incubated overnight in $150 \mathrm{ml}$ demi-water containing $0.5 \mathrm{~g}$ glucose and four drops of Tween 80 to increase germination success. The next day, the seeds were washed three times for $1 \mathrm{~min}$ in $70 \%$ ethanol, two times with bleach, and four times in sterile demi-water. Seeds were germinated on 0.5 Potato Dextrose Agar plates [24] for 3 weeks at $20^{\circ} \mathrm{C}$. The Carex seedlings that appeared to be free of microbial contaminants (no bacterial or fungal growth was seen for the germinated seeds on PDA) were further cultivated for about three weeks of $16 \mathrm{~h}$ at $22^{\circ} \mathrm{C}$ and $8 \mathrm{~h}$ at $10^{\circ} \mathrm{C}$ day-night cycle $\left(100 \mu\right.$ mol PAR m $\left.{ }^{-2} \mathrm{~s}^{-1}\right)$ in pots filled with sterile glass beads ( $1 \mathrm{~mm}$ diameter) and 0.5 Hoagland medium $\quad\left(590.4 \mu \mathrm{g} \mathrm{ml}^{-1} \quad \mathrm{Ca}\left(\mathrm{NO}_{3}\right)_{2} \cdot 4 \mathrm{H}_{2} \mathrm{O}, \quad 253.0 \mu \mathrm{g} \mathrm{ml}^{-1}\right.$ $\mathrm{KNO}_{3}, 68.1 \mu \mathrm{g} \mathrm{ml}^{-1} \mathrm{KH}_{2} \mathrm{PO}_{4}, 246.5 \mu \mathrm{g} \mathrm{ml}^{-1} \mathrm{MgSO}_{4} \cdot 7 \mathrm{H}_{2} \mathrm{O}$, $2.9 \mu \mathrm{g} \mathrm{ml}^{-1} \quad \mathrm{H}_{3} \mathrm{BO}_{3}, 1.8 \mu \mathrm{g} \mathrm{ml}^{-1} \quad \mathrm{MnCl}_{2} \cdot 4 \mathrm{H}_{2} \mathrm{O}, 0.2 \mu \mathrm{g} \mathrm{m}^{-1}$ $\mathrm{ZnSO}_{4} \cdot 7 \mathrm{H}_{2} \mathrm{O}, \quad 0.1 \mu \mathrm{g} \mathrm{ml}^{-1} \quad \mathrm{CuSO}_{4} \cdot 5 \mathrm{H}_{2} \mathrm{O}, \quad 0.1 \mu \mathrm{g} \mathrm{ml}^{-1}$ $\mathrm{Na}_{2} \mathrm{MoO}_{4} \cdot 2 \mathrm{H}_{2} \mathrm{O}$, and $41.5 \mu \mathrm{g} \mathrm{ml}^{-1}$ ferric EDTA). To stop the developing process the plants were kept at $4{ }^{\circ} \mathrm{C}$ with a $10 \mathrm{~h}$ day-night cycle. After about 5 weeks, seedlings were transferred from glass beads to gamma-sterilized soil [27] containing $14.3 \mu \mathrm{l}$ per gram soil sterile demi-water, $13.5 \mu \mathrm{l}$ per gram soil sterile P-buffer (18.4 mM KH $\left.\mathrm{PO}_{4}, \mathrm{pH} 6.5\right), 65.7 \mu \mathrm{l}$ per gram soil sterile macronutrient stock solution $(\mathrm{pH} 6.5)$, and $0.9 \mu \mathrm{l}$ per gram soil sterile micronutrient stock solution. The macronutrient stock consisted of $10.7 \mathrm{mg} \mathrm{ml}^{-1} \mathrm{MES}, 1.6$ $\mathrm{mg} \mathrm{ml}^{-1} \quad \mathrm{NH}_{4} \mathrm{NO}_{3}, \quad 0.5 \mathrm{mg} \mathrm{ml}^{-1} \quad \mathrm{~K}_{2} \mathrm{SO}_{4}, \quad 2.6 \mathrm{mg} \mathrm{ml}^{-1}$ $\mathrm{MgSO}_{4} \cdot 7 \mathrm{H}_{2} \mathrm{O}$, and $0.3 \mathrm{mg} \mathrm{ml}^{-1} \mathrm{CaCl}_{2} \cdot 2 \mathrm{H}_{2} \mathrm{O}$. Fifty milliliters of micronutrient stock solution consisted of $20 \mathrm{ml}$ solution 1 (2.6 mg ml${ }^{-1} \mathrm{H}_{3} \mathrm{BO}_{3}, 1.6 \mathrm{mg} \mathrm{ml}^{-1} \mathrm{MnCl}_{2} \cdot 4 \mathrm{H}_{2} \mathrm{O}$ ), $20 \mathrm{ml}$ solution $2\left(1.5 \mathrm{mg} \mathrm{ml}^{-1} \quad \mathrm{FeCl}_{2} \cdot 4 \mathrm{H}_{2} \mathrm{O}\right), 5 \mathrm{ml}$ solution 3 $\left(0.4 \mathrm{mg} \mathrm{ml}^{-1} \mathrm{ZnCl}_{2}, 0.2 \mathrm{mg} \mathrm{ml}^{-1} \mathrm{CuCl}_{2} \cdot 2 \mathrm{H}_{2} \mathrm{O}, 0.1 \mathrm{mg} \mathrm{ml}^{-1}\right.$ $\mathrm{NiCl}_{2} \cdot 6 \mathrm{H}_{2} \mathrm{O}, 0.1 \mathrm{mg} \mathrm{ml}^{-1} \mathrm{CoCl}_{2} \cdot 6 \mathrm{H}_{2} \mathrm{O}$ ), and $5 \mathrm{ml}$ solution 4 (13.0 mg ml ${ }^{-1} \quad \mathrm{Na}_{2}$ EDTA, $0.5 \mathrm{mg} \mathrm{ml}^{-1} \quad \mathrm{Na}_{2} \mathrm{MO}_{4} \cdot 2 \mathrm{H}_{2} \mathrm{O}$ ). Carex plants were incubated at $20^{\circ} \mathrm{C}$ and $16 / 8 \mathrm{~h}$ day-night cycle $\left(282 \mu \mathrm{mol} \mathrm{PAR} \mathrm{m}^{-2} \mathrm{~s}^{-1}\right)$ and regularly watered with sterile demi-water.

\section{Infection bioassay}

Infection bioassays with $F$. culmorum were performed with 4-week- old $C$. arenaria plants which were previously cultivated on glass beads. The plants were infected with $F$. culmorum by dipping the roots into $10^{7} \mathrm{ml}$ ${ }^{-1}$ spore suspension and planting it in F. culmoruminfected soil ( $9 \% \mathrm{w} / \mathrm{w}$ moisture) which was pre-incubated for 4 days at $20^{\circ} \mathrm{C}$ with $10^{5}$ per gram soil spores, $0.45 \mathrm{mg}$ per gram soil glucose, $12.0 \mu \mathrm{l}$ per gram soil P-buffer $(18.4 \mathrm{mM}), 58.2 \mu \mathrm{g} \mathrm{g}^{-1}$ soil macronutrient stock solution, and $0.8 \mu \mathrm{g} \mathrm{g}^{-1}$ soil micronutrient stock solution. For the control treatment, demi-water instead of spore suspension was added. Plants were incubated at day-night cycles of $16 \mathrm{~h}$ at $22^{\circ} \mathrm{C}$ and $8 \mathrm{~h}$ at $10{ }^{\circ} \mathrm{C}\left(100 \mu \mathrm{mol} \mathrm{PAR} \mathrm{m} \mathrm{s}^{-2} \mathrm{~s}^{-1}\right)$ and regularly watered with sterile demi-water. Infection symptoms were weekly monitored. After 5 weeks, plants were harvest to determine the shoot and root fresh weight. 


\section{Olfactometer system}

To test the attraction of bacteria in soil to VOCs emitted by plant root or fungi, an olfactometer was developed (Coelen Glastechniek, Cuijk, The Netherlands). The olfactometer consisted of a central glass vessel $(4.5 \mathrm{~cm}$ diameter, $6.5 \mathrm{~cm}$ high) and four rectangular glass tubes $(5.0 \mathrm{~cm}$ length [4.6 $\mathrm{cm}$ inner length] and $1.5 \mathrm{~cm}$ high $[1.3 \mathrm{~cm}$ inner height]; Fig. 2a). The glass tubes being open at the top to fill in soil and inoculate the bacteria were connected to the central vessel (in $1.5 \mathrm{~cm}$ height from the bottom) via screw thread adapter couplings ( $4.0 \mathrm{~cm}$ length) with integral PTFE-faced silicone seals (DURAN Group GmbH, Wertheim/Main, Germany). The other side of the glass tubes was closed with screw caps (with PTFE silicone seal; DURAN Group $\mathrm{GmbH}$ ). The top of the glass tube was closed with a glass lid fixed with parafilm. The connection part between the central vessel and the soil-filled part in the glass tube had a length of about $4.5 \mathrm{~cm}$ (Fig. 2a). In between the central glass vessel and screw thread adapter couplings a nylon membrane of $1 \mu \mathrm{m}$ mesh size (Plastok Associates Ltd, Birkenhead, UK) was placed to prevent potential passing of fungal hyphae or spores from soil in the central vessel into the glass tubes.

\section{Olfactometer bioassay}

The set-up of the olfactometer bioassay consisted of four different treatments (Fig. 2a): Control $(n=3), F$. culmorum $(n=3)$, Carex $(n=4)$, and Carex inoculated with $F$. culmorum $(n=4)$. The control treatments without plants and fungus consisted of $90 \mathrm{~g}$ soil mixed with $1.3 \mathrm{ml}$ demi-water, $4.5 \mathrm{ml}$ P-buffer $\left(10 \mathrm{mM} \mathrm{KH} \mathrm{PO}_{4}, \mathrm{pH} 6.5\right)$, and $2.7 \mathrm{ml}$ artificial root exudate solution (ARE, [27]). For the treatment with $F$. culmorum, $32.5 \mathrm{~g} F$. culmorum-infected soil was pre-incubated for 10 days with $3 \times 10^{5}$ spores per gram soil, $0.95 \mathrm{mg}$ per gram soil glucose, $0.04 \mathrm{ml}$ per gram soil Pbuffer, and $0.01 \mathrm{ml}$ per gram soil demi-water at $20^{\circ} \mathrm{C}$. This soil was mixed with $60 \mathrm{~g}$ dry soil, $3.29 \mathrm{ml} 10 \mathrm{mM}$ P-buffer, and $2.7 \mathrm{ml}$ ARE. The final carbon content for the treatments supplied with ARE was $222 \mu \mathrm{g} \mathrm{C}$ per gram soil. Five-weekold Carex plants were treated or non-treated with $\mathrm{F}$. culmorum and incubated for 5 days with the same day-night cycle conditions as described above. In brief, root tips of Carex plants were dipped in $F$. culmorum spore suspension $\left(1.1 \times 10^{7}\right.$ spores $\left.\mathrm{ml}^{-1}\right)$ and planted into sterile hand-made nylon bags $(0.5 \mathrm{~mm}$ mesh size, about $100 \mathrm{ml}$ volume) containing $60 \mathrm{~g}$ soil mixed with macro- and micronutrients as described above and $32.5 \mathrm{~g}$ of $F$. culmorum-infected soil (see above) which was pre-incubated for 6 days at $20^{\circ} \mathrm{C}$. For the non-treated plants, root tips of the Carex plants were dipped in sterile demi-water and planted in sterile nylon bags containing $90 \mathrm{~g}$ soil, demi-water, phosphate-buffer as well as macro- and micronutrients. The soil moisture in all central vessels was $9.4 \% \mathrm{w} / \mathrm{w}$.

For each treatment, two of four glass tubes connected to a central pot were filled with $10 \mathrm{~g}$ soil mixed with $0.5 \mathrm{ml} \mathrm{P-}$ buffer $\left(10 \mathrm{mM} \mathrm{KH}_{2} \mathrm{PO}_{4}\right.$, pH 6.5) and $0.3 \mathrm{ml}$ ARE to obtain a final carbon concentration of $148 \mu \mathrm{g} C$ per gram soil. The other two glass tubes were filled only with soil $(10 \mathrm{~g})$ mixed with $0.8 \mathrm{ml}$ P-buffer (Fig. 2a). At the end of each glass tube $(8.0 \% \mathrm{w} / \mathrm{w}$ soil moisture), $100 \mu \mathrm{l}$ of bacterial suspension consisting of six different bacteria was inoculated. Before, overnight cultures of the bacteria were set up [27] and harvest by centrifuging for $10 \mathrm{~min}$ at $5500 \mathrm{rpm}$ and $18^{\circ} \mathrm{C}$, followed by two times washing steps with P-buffer and OD adjustment to obtain $10^{8} \mathrm{CFU} \mathrm{ml}^{-1}$. The bacterial suspensions were finally diluted to about $5 \times 10^{5} \mathrm{CFU} \mathrm{ml}^{-1}$ and mixed. After filling, closing and connecting all glass tubes the nylon bags with the soil and plants were added to the system. The olfactometer system was covered with aluminum foil (Supplementary Information Appendix S1 and Figure S1) and incubated at $20^{\circ} \mathrm{C}$ with a $16 / 8 \mathrm{~h}$ day-night cycle.

After about $65 \mathrm{~h}$, soil in distance of $0.8 \mathrm{~cm}$ from the connection point (Fig. 2a) was collected from each glass tube and stored at $-80^{\circ} \mathrm{C}$ till DNA extraction. Plants were harvested, carefully rinsed with water, and scanned with an Epson Perfection V850 Pro Scanner. Furthermore, infected and non-infected parts of the root were microscopically visualized with Leica MD641 and Leica Application Suite Version 4.7.0 (Leica Microsystems B.V., Amsterdam, The Netherlands).

\section{Volatile collection and analysis}

VOCs released in the soil from $F$. culmorum or Carex roots were collected with steel traps filled with $150 \mathrm{mg}$ Tenax TA and $150 \mathrm{mg}$ Carbopack B (Markes International Ltd, Llantrisant, UK). The traps were connected to glass vessels (4.5 $\mathrm{cm}$ diameter and $6.5 \mathrm{~cm}$ height) with two outlets at the side (Supplementary Information Appendix S1 a and Figure S2). The vessels contained nylon bags filled with soil, soil and $F$. culmorum, or soil and Carex plants similar to the treatments described above. For each treatment, VOCs of four replicates were collected for $24 \mathrm{~h}$ simultaneously by two traps per vessel. Traps were removed, capped, and stored at $4{ }^{\circ} \mathrm{C}$ until GC-MS analysis (Supplementary Information, Appendix S1).

\section{Diffusion assay of volatile pure compounds in soil}

For testing the diffusion ability of pure volatile compounds, a mix of VOCs representative for the VOCs blend produced by Carex roots and/or F. culmorum was used (Supplementary material Appendix S1 and S2, Tables S2 and S4). 
A glass olfactometer system was set-up with a central glass vessel $(4.5 \mathrm{~cm}$ diameter, $6.5 \mathrm{~cm}$ high) and two rectangular glass tubes $(12.5 \mathrm{~cm}$ length and $1.1 \mathrm{~cm}$ high), which were connected via screw thread adapter couplings (see above) to the central vessel (Fig. 4a). Both, central vessel and glass tubes were covered with aluminum foil, which was fixed with parafilm to minimize evaporation of the volatile compounds. The central vessel contained $60 \mathrm{~g}$ soil mixed with sterile demi-water $(9.4 \%$ humidity $[w / w])$. Fifteen grams soil was mixed with $10 \mathrm{mM}$ P-buffer $(8 \% \mathrm{w} / \mathrm{w}$ humidity) and filled into the glass tube. About $0.55 \mathrm{ml}$ of a mix of pure VOCs (about $5 \mathrm{mM}$ in $100 \%$ methanol) was pipetted in about $2 \mathrm{~cm}$ depth next to the connection points in the central vessel resulting in a final VOCs concentration of $0.1 \mathrm{mM}$ per gram soil. VOCs were collected with Rotilabo®-silicone tubes (PDMS tubes; Carl Roth $\mathrm{GmbH}+\mathrm{Co}$. $\mathrm{KG}$, Karlsruhe, Germany), which were placed into the soil of the central vessel as well as in the glass tubes at five different distances (Fig. 4a). The PDMS tubes were pretreated as described by Kallenbach et al. [28]. After 30 or $60 \mathrm{~min}$, PDMS tubes were removed and kept at $-20^{\circ} \mathrm{C}$ until analysis. The experiment was replicated six times. To compare different diffusion abilities of the pure VOCs, a relative peak area was calculated: Relative peak area $=\mathrm{Peak}$ area at distance Dn/Peak area at distance D1.

\section{DNA extraction and $q P C R$}

DNA extraction was performed with DNeasy PowerSoil Kit (Qiagen Benelux B.V., Venlo, The Netherlands) as described in Supporting Information, Appendix S1. The DNA was quantified by NanoDrop and stored at $-20{ }^{\circ} \mathrm{C}$ until use.

All quantitative PCR (qPCR) were performed with a BioRad CFX96 C1000 Touch $^{\text {TM }}$ Thermal cycler according to the protocols described in Supplementary Information, Appendix S1. To transform qPCR data from 16S rRNA copy number into cell number, the $16 \mathrm{~S}$ rRNA copy for each strain was determined, if not known from studies before (e.g. [29]), by qPCR of genomic DNA extracted from the same liquid culture where CFU were counted in parallel. The obtained cell numbers were corrected by the initial soil weight used for DNA extraction.

\section{Statistics}

Multivariate analysis of processed and normalized (log transformation and mean centered) GC-MS data was conducted with MetaboAnalyst 3.0 (http://www.metaboanalyst. ca/MetaboAnalyst, Xia et al. 2015 [30]). VOCs were accounted as produced for each treatment when the average peak intensity for all replicates per treatment was at least two-fold higher and significantly different (Student's $t$-test, $P<0.05)$ from the controls.
Differences in bacterial abundance per treatment observed by qPCR and differences in relative peak areas of diffused VOCs were analyzed with R 3.1.1 (http:// www.r-project.org/) using Anova followed by Tukey's HSD test [31]. Data were prior log- or square roottransformed to obtain normality of errors. Student's $t$-test was applied to analyze differences in the root and shoot biomass of Carex plants incubated with or without $F$. culmorum. Differences obtained by statistical tests were considered significant for $P<0.05$.

\section{Results}

\section{Infection of C. arenaria by F. culmorum PV}

Inoculation of $C$. arenaria with the soil-borne fungus $F$. culmorum PV resulted in a significant reduction of plant biomass. The root and shoot weight of infested plants was about seven times lower as compared to control plants (Table 1). Roots and leaves of almost all plants treated with the fungus were completely wilted after 5 weeks of incubation (Figure S3), demonstrating that $F$. culmorum can be pathogenic to $C$. arenaria. Carex plants used for testing the attraction of soil bacteria by root VOCs showed clear infection symptoms belowground (dark brown dots at roots) after 8 days of incubation (Fig. 1 and Supplementary Information Appendix S2, Figure S4). Furthermore, fungal growth was visible at the bottom of the shoot (Appendix S2 and Figure S4L).

\section{Bacterial attraction by root VOCs of $\mathrm{C}$. arenaria}

To evaluate a potential stimulation of bacterial migration in soil, towards VOCs released by $F$. culmorum or by $C$. arenaria, an olfactometer system was set up (Fig. 2 and Supplementary Information Appendix S1 and Figure S1). In this system, bacteria inoculated at one end in a soilcontaining glass tube could migrate towards VOCs that were produced by $C$. arenaria or $F$. culmorum in the central vessel. Migrated bacteria in the glass tubes were collected and quantified by qPCR. In the treatments with $C$. arenaria, the bacterial cell number per strain was up to three times

Table 1 Plant biomass of Carex arenaria grown for 5 weeks in gamma-sterilized soil with or without (control) the soil-borne fungus Fusarium culmorum PV

\begin{tabular}{lll}
\hline Treatment & Shoot fresh weight $(\mathrm{mg})$ & Root fresh weight $(\mathrm{mg})$ \\
\hline Control & $321 \pm 88$ & $475 \pm 148$ \\
F. culmorum & $45 \pm 73^{*}$ & $66 \pm 129 *$ \\
\hline
\end{tabular}

Asterisk indicate significant difference between control and $F$. culmorum-treated plants $(P<0.05)$ 
Fig. 1 Roots of Carex arenaria growing for 8 days in absence (a-e) or presence of the soilborne fungus Fusarium culmorum PV (f-j). Black arrows $(\mathbf{f}-\mathbf{i})$ indicate infection areas of the fungus at roots of Carex plants. Bars in panel $(\mathbf{e}, \mathbf{j})$ showing non-infected and infected root parts, respectively, represent $500 \mu \mathrm{m}$ size
Non-infected C. arenaria

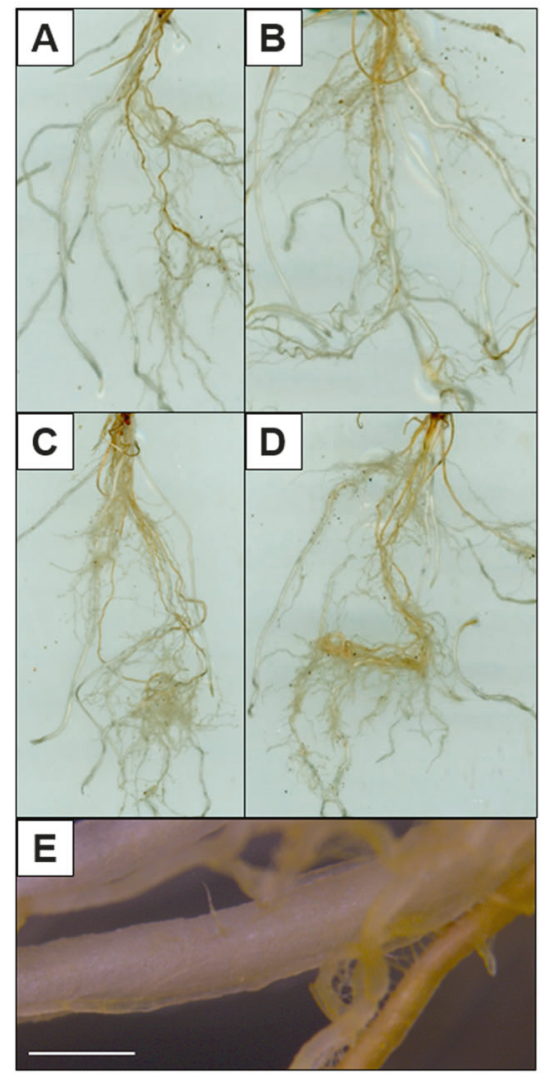

Infected C. arenaria

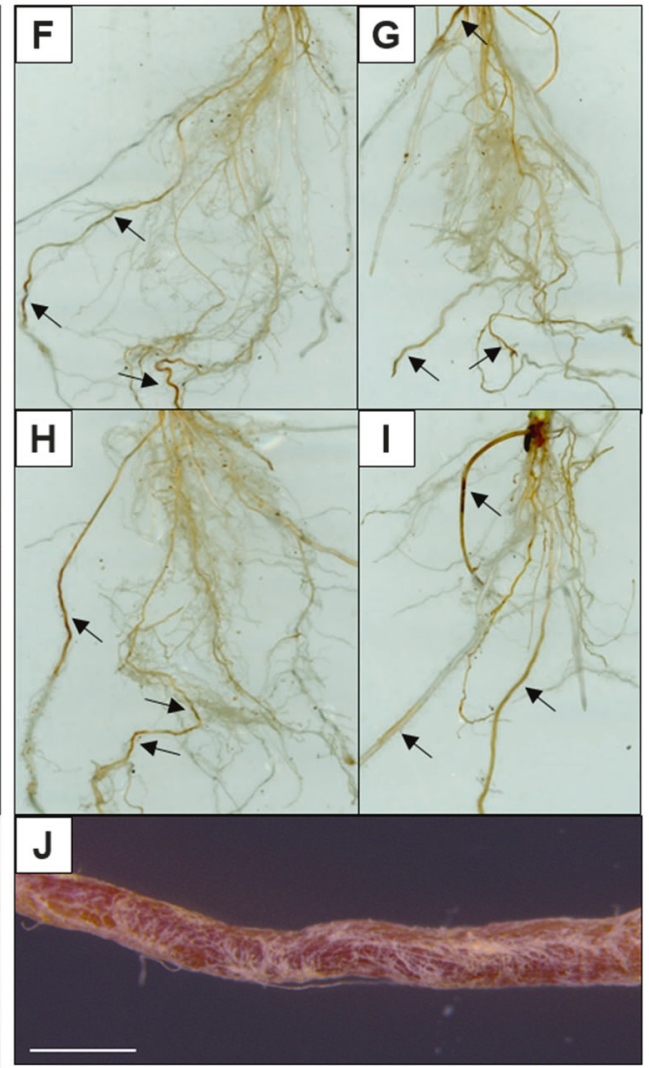

higher as compared to the treatment consisting only of soil (Fig. 2b), indicating that volatiles emitted from plant roots can attract soil bacteria.

The stimulation of bacterial motility by plant VOCs released in presence or absence of $F$. culmorum was dependent on the access of nutrients. For example, stimulation of Paenibacillus was only observed by additional access to artificial root exudates while other bacteria (e.g. Burkholderia) were less attracted by the root VOCs in the presence of nutrients (Fig. 2b).

The cell numbers of bacteria inoculated in soil supplied with ARE was about 30-1000 times higher (with exception for Dyella) as compared to bacterial cell numbers in soil without ARE (Appendix S2 and Table S3). The number of migrated bacteria at the end of the glass tubes filled with soil supplied with ARE were mostly above the amount of initial inoculum (Fig. 2b). The ratios of migrated cells towards Carex to migrated cells in the control were significant higher for Burkholderia, Dyella, and Pseudomonas (1.8-3.3) when they were inoculated in soil without ARE as compared to the conditions with access to ARE (0.5-1.6; Appendix S2 and Table S3).

Using the olfactometer approach we tested if the infection of $C$. arenaria with the fungal pathogen $F$. culmorum
(Fig. 1) affected the VOCs profiles (see below) and consequently bacterial attraction. For Janthinobacterium, Collimonas, and Paenibacillus the numbers of migrated cells in soil supplied with ARE $\left(2.6 \times 10^{5}-2.1 \times 10^{9}\right.$ cells per gram soil) were significant higher for the Carex plants infected with $F$. culmorum as compared to non-infected Carex plants $\left(1.4 \times 10^{5}-1.5 \times 10^{9}\right.$ cells per gram soil) and to the control $\left(1.4 \times 10^{5}-3.3 \times 10^{8}\right.$ cells per gram soil; Fig. $2 \mathrm{~b}$ and Supplementary Information Appendix S2 and Table S3). This suggests that specific bacteria can be attracted to root volatiles of plants infected by a fungal pathogen. Interestingly, in the treatments inoculated only with $F$. culmorum without plants the number of migrated bacteria $\left(1.8 \times 10^{3}-2.5 \times 10^{6}\right.$ cells per gram soil without ARE and $7.1 \times 10^{4}-9.5 \times 10^{8}$ cells per gram soil with ARE) was not different or even significant lower as compared to the control $\left(1.6 \times 10^{2}-2.2 \times 10^{6}\right.$ cells per gram soil without ARE and $8.8 \times 10^{4}-3.3 \times 10^{8}$ cells per gram soil with ARE; Fig. $2 b$ and Supplementary Information Appendix S2 and Table S3). This indicates that VOCs emitted by the fungus in the absence of Carex could not stimulate bacterial motility and some bacteria like Burkholderia and Janthinobacterium were repelled (Fig. 2b). 
A
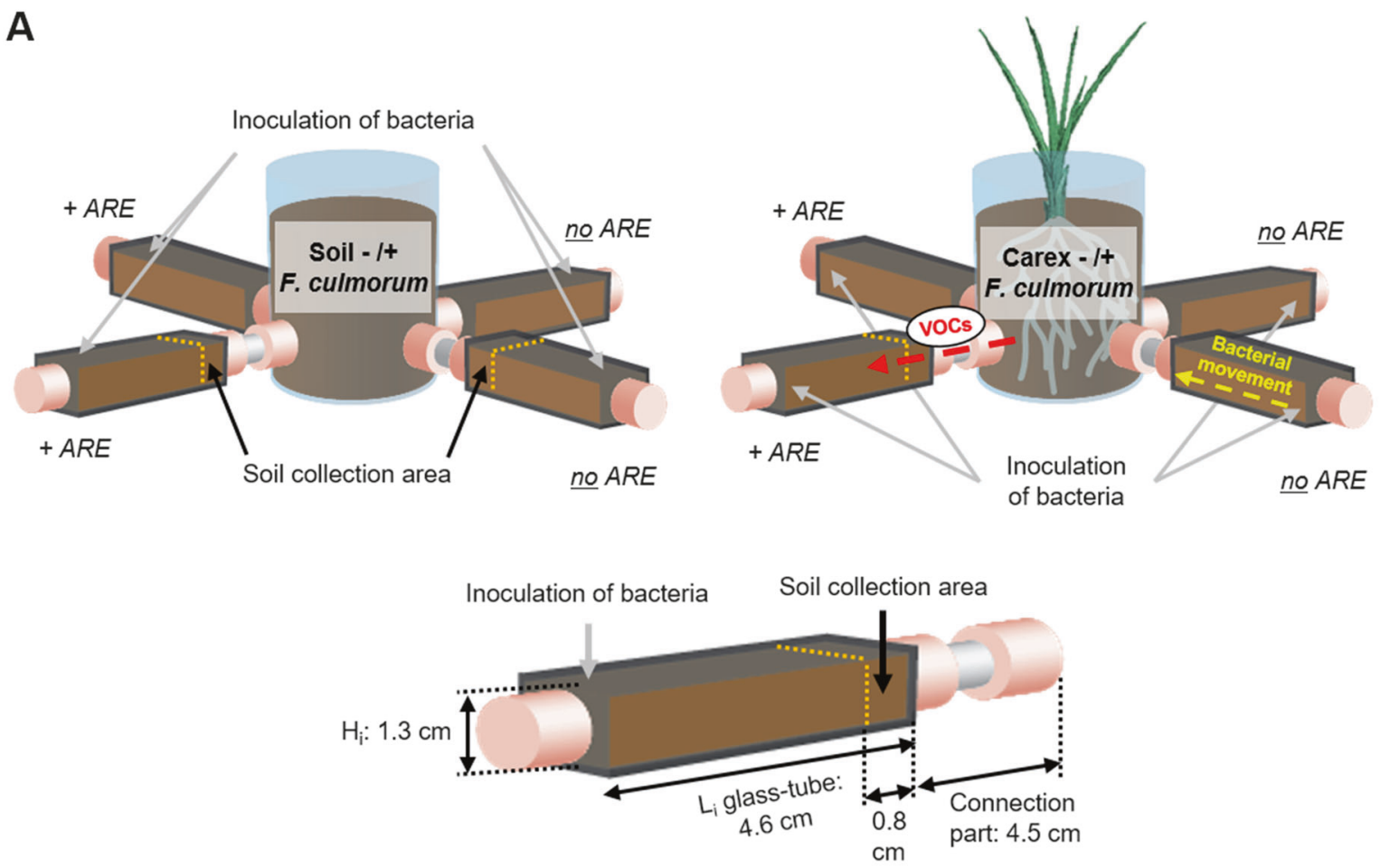

B
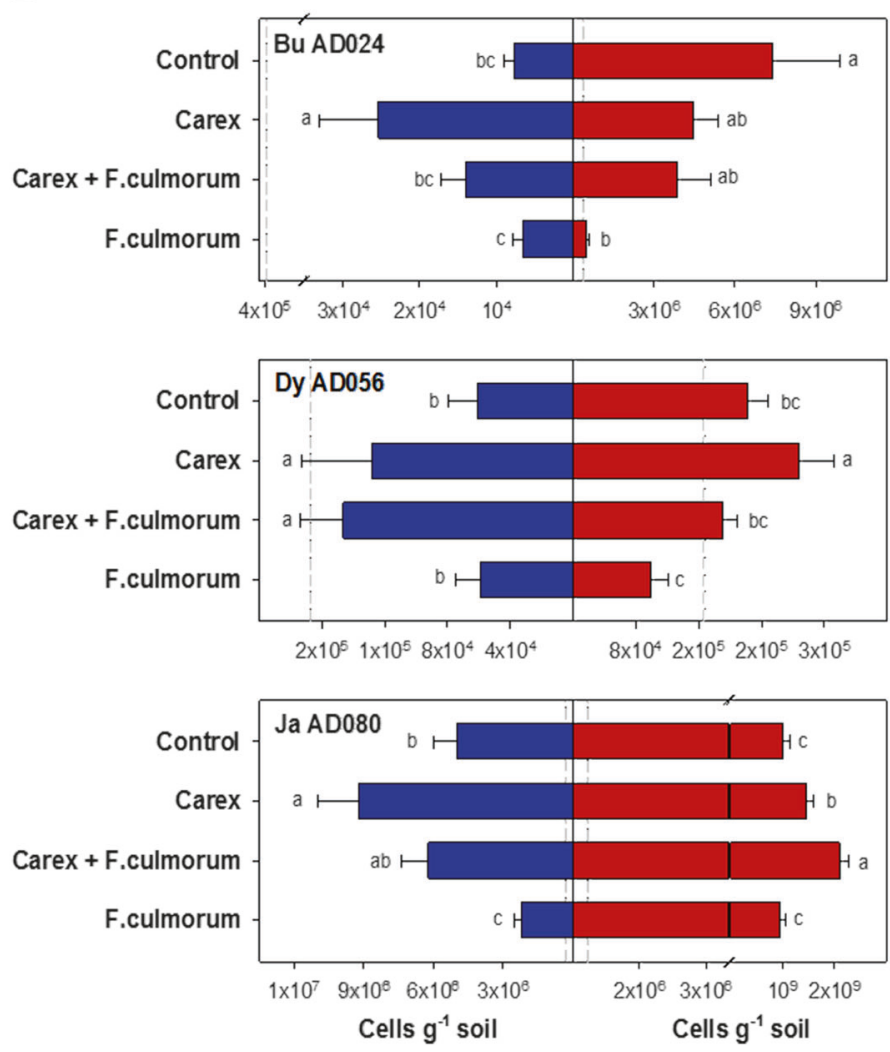

no ARE
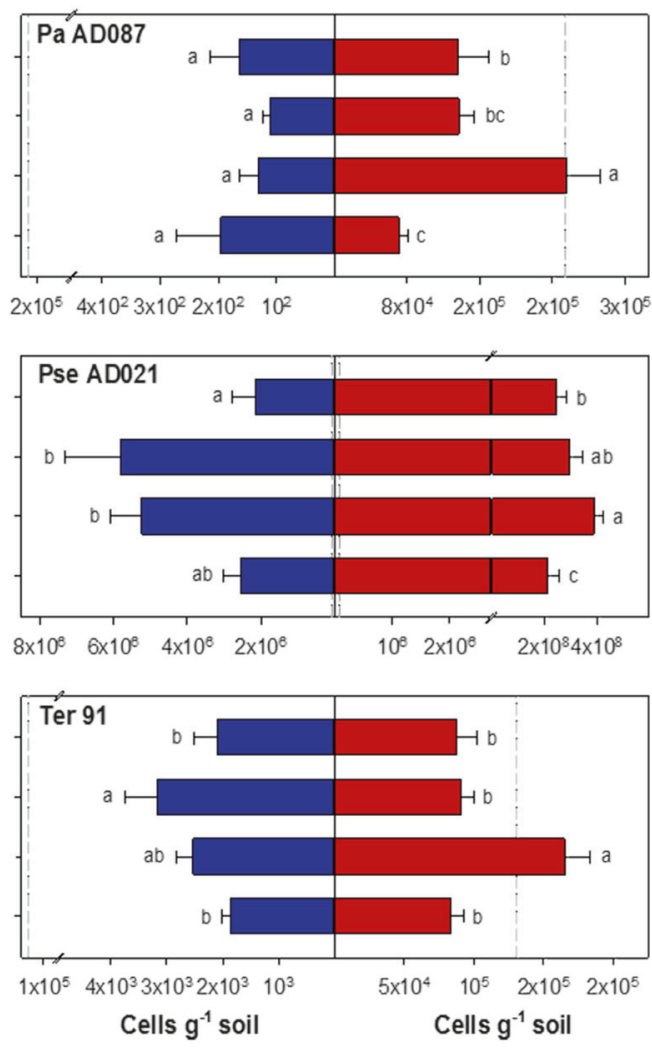
Fig. 2 Bacterial attraction towards VOCs in soil. a A glass olfactometer system with four different treatments in the central vessel: control (only soil); soil with F. culmorum; Carex, and Carex with F. culmorum. Connected glass tubes contained soil mixed with (+ARE) or without artificial root exudates (no ARE). A synthetic bacterial community including Burkholderia sp. AD024, Dyella sp. AD056, Janthinobacterium sp. AD080, Paenibacillus sp. AD087, Pseudomonas sp. AD021, and Collimonas pratensis Ter91 was inoculated into soil at one end of the glass tube. After $65 \mathrm{~h}$ soil was collected at $0.8 \mathrm{~cm}$ distance from the connection part to the central vessel (i.e. $3.8 \mathrm{~cm}$ distance from the inoculation point) (a) to quantify the migrated bacteria. Drawing is not true to scale. b Bacterial number obtained by qPCR of the 16S rRNA gene at the collection area. 16S rRNA gene copy numbers were transformed into cell number based on the known copy number of the gene per genome. Different letters represent significant differences between the four treatments. Gray dotted line indicates initial bacterial concentration added at the inoculation point. $\mathrm{H}_{\mathrm{i}}$, height of inner filling area, $\mathrm{L}_{\mathrm{i}}$ length of inner filling area, VOCs volatile organic compounds

\section{VOCs emission from the rhizosphere of infected and non-infected $C$. arenaria plants and $F$. culmorum in soil}

A distinct blend of VOCs was emitted by different treatments (Appendix S2 and Table S4) and clear separations between the roots of $C$. arenaria, the fungus $F$. culmorum, and the control based on partial least-squares discriminant analysis were observed (Fig. 3a). Although the VOC profiles of $C$. arenaria in the presence and absence of $F$. $c u l$ morum formed two distinct groups, these VOCs were more similar as compared to the VOCs profile of $F$. culmorum only (Fig. 3). In total, most VOCs were detected for the treatments of $C$. arenaria inoculated with $F$. culmorum (86 versus 70 and 57 compounds for the treatments Carex and F. culmorum, respectively; Appendix S2, Table S4). The identified VOCs released by infected or non-infected plant roots belonged to the classes of aromatic compounds (49-51\%), e.g. benzofuran or benzonitrile, and ester (14-17\%) such as $\gamma$-capro-, $\gamma$-deca or $\gamma$-nonalactone (Fig. 3 and Appendix S2 and Table S4). Interestingly, in the presence of the fungus $F$. culmorum more alkanes and the monoterpene $(\mathrm{Z})$-limonene-oxid were produced in the rhizosphere of $C$. arenaria (Fig. 3 and Appendix S2 and Table S4). Most of the VOCs emitted by $F$. culmorum in soil were terpenes $(21 \%)$ such as $\alpha$-pinene or camphene and ketones (19\%) like 2-nonanone or 3-octanone (Fig. 3 and Appendix S2 and Table S4). In addition, several compounds were detected, which could not be assigned with certainty to a classified volatile organic compound and remained unknown.

\section{Diffusion of pure VOCs in soil}

The diffusion of pure VOCs representative of $C$. arenaria or $F$. culmorum VOCs blend (Supplementary Information
Appendix S1 and Table S2) was measured in soil at various distances (Fig. 4a). Except for Amylene hydrate all VOCs were traceable until a distance of $12 \mathrm{~cm}$ (Fig. 4b). For most compounds such as benzofuran or benzonitrile the detectable amounts decreased drastically with sampling distance. To compare the different diffusion abilities of the pure VOCs, a relative peak area in relation to the amount detected at the starting point was calculated. The VOCs propanal, $\gamma$-nonalactone and dimethyl disulfide had the highest relative peak areas ( $>75 \%$; Supplementary Information Appendix S2 and Table S5). Hence, some VOCs diffuse better over a long distance as compared to other compounds. The diffusion profile for $\alpha$-pinene and camphene was very different, although these compounds belong to the same chemical class (monoterpenes) (Fig. 4b). At 12 $\mathrm{cm}$ distance, the traceable amount of $\alpha$-pinene was about 30 times lower as compared to camphene (Supplementary Information Appendix S2 and Table S5).

\section{Discussion}

Plant release a wide range of secondary metabolites through their roots including VOCs. A main role of those compounds is considered to be a defense as they are often used to fight off herbivory, pests, and pathogens [10, 32]. Although VOCs are generally considered as easily diffusible compounds in the soil matrix and important for belowground plant interactions [9], limited knowledge exist about the role of plant VOCs for attracting beneficial soil organisms.

Here, we developed a glass olfactometer system in order to test the attraction of soil bacteria from a synthetic community to VOCs emitted by the roots of $C$. arenaria or by the plant-pathogenic fungus $F$. culmorum. Olfactometer systems have been used successfully to study aboveground plant-herbivories interactions [33, 34] or belowground plant-nematode interactions (e.g. [17]). However, this is the first case to apply an olfactometer to study plant-microbe interactions.

Here, we revealed for the first time that VOCs emitted by plant roots play an important role in the long-distance attraction of bacteria from bulk soil. Interestingly, the addition of nutrients to the bulk soil in the form of ARE influenced the VOC-mediated plant-bacteria interactions. For example, Burkholderia, Dyella, and Pseudomonas were attracted less by root VOCs in the presence of nutrients while Paenibacillus was attracted only when additional nutrients were added to the bulk soil. These results suggests that under nutrient limitation certain bacteria might be intensely attracted by plant VOCs. Hence, plant VOCs can act as infochemicals providing information about a nearby nutrient-rich environment. It is plausible that some 
A

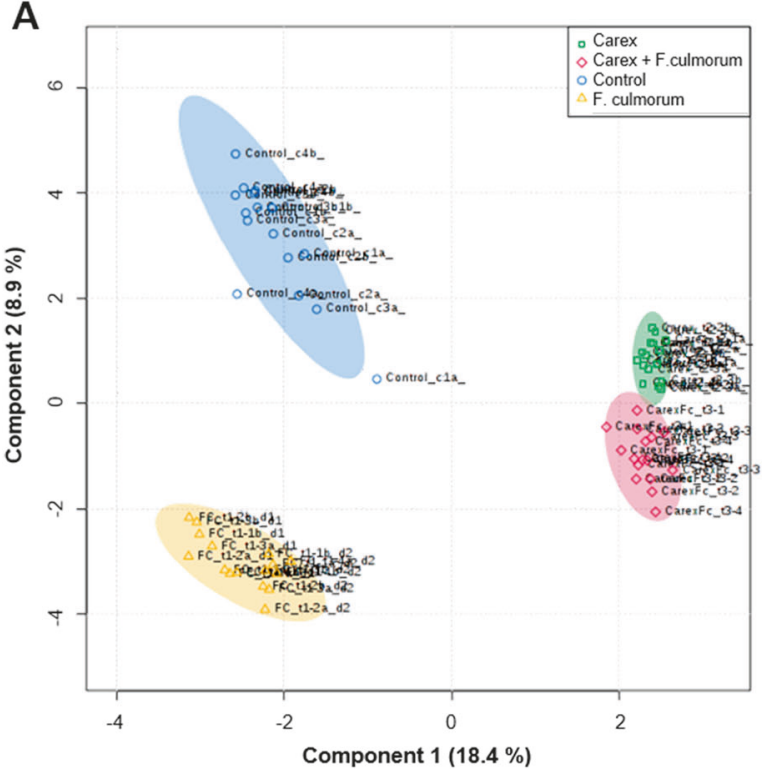

B

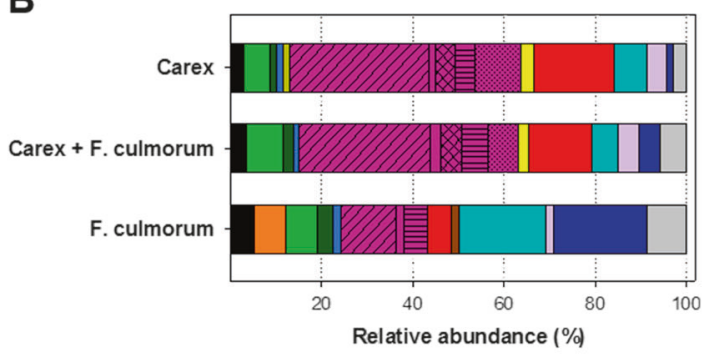

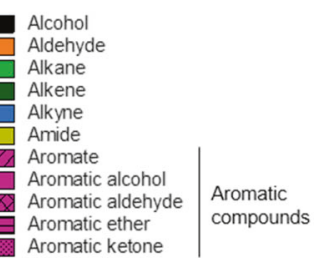

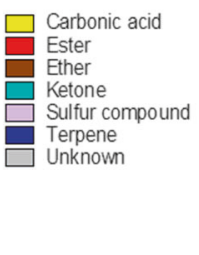

included in the analysis. b Relative abundance of identified VOCs per compound class (see legend) and treatment. Unknown: VOCs that could not be assigned with certainty to a known compound in the reference libraries

defense against pathogens. For instance, benzofuran and benzofuran as well as acetophone, benzaldehyde, or nonanoic acid were previously shown to be root exudates components with antifungal activity [39-43]. Besides fighting against potential pathogens, specific root VOCs of C. arenaria can be involved in the attraction of distant bacteria. For example, it was reported that the ester $\gamma$ caprolactone can enhance the colonization of potato roots by Rhodococcus or Pseudomonas when applied in a hydroponic system [44]. Also for dimethyl disulfide despite its antifungal activity [45], an attraction of soil organisms such as nematodes has been reported previously [46] and it can stimulate bacterial growth [23]. This suggests that same VOCs can fulfill different functions depending on the interacting partner.

Fungal infection affected the VOCs profile of $C$. arenaria and led to the emission of VOCs such as the monoterpene (Z)-limonene-oxid. Interestingly, an induction of terpene and terpenoid production upon fungal infection was previously observed for various plants [19-22], indicating that those compounds might play an important role in plant-pathogen interactions or attraction of beneficial bacteria important for plant protection.

The fungus $F$. culmorum emitted a specific blend of VOCs dominated by terpenes. Recently, it was demonstrated that those VOCs play an important role in the longdistance interaction with bacteria by affecting both motility and production of secondary metabolites [24, 47]. Here, VOCs of $F$. culmorum did not significantly stimulated 
A

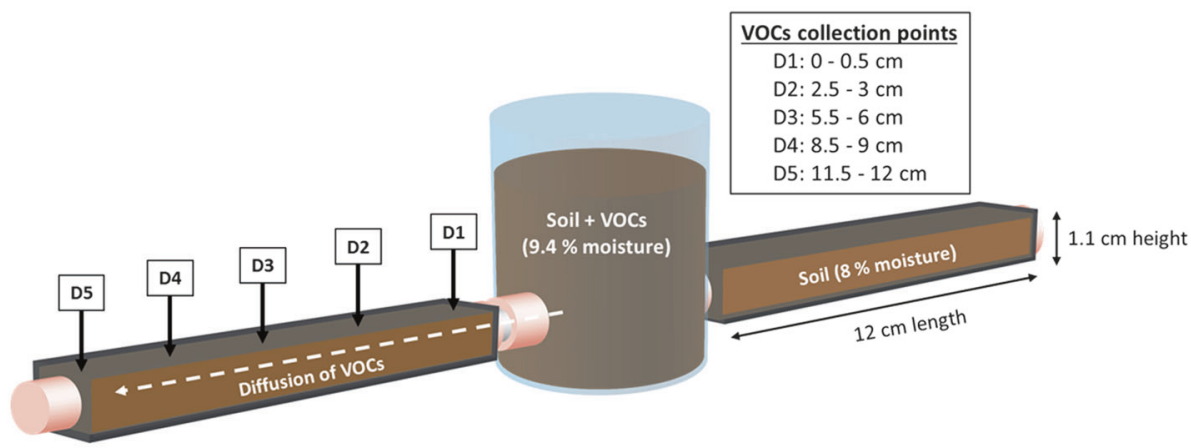

B

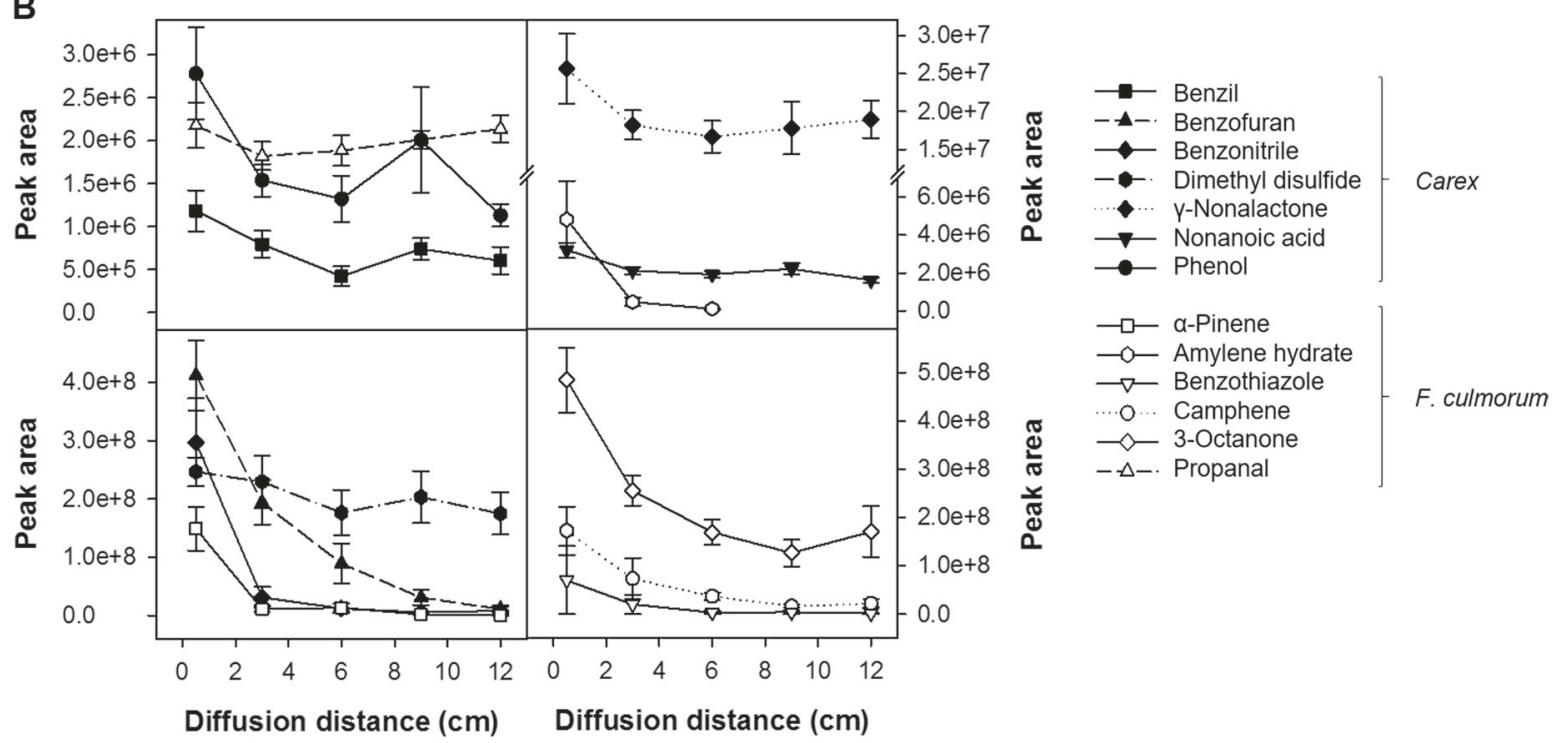

Fig. 4 Diffusion of pure VOCs along a distance of $12 \mathrm{~cm}$ in soil. VOCs were collected with PDMS tubes for 30 and 60 min at different distances in the connected glass tubes 1 and 2, respectively (a). Data show mean values and standard errors $(N=6)$ for each synthetic compound after $60 \mathrm{~min}$ of collection (b). Filled and open symbols

bacterial motility and function as repellence as in the case of Burkholderia or Janthinobacterium. In accordance to previously reported antibacterial activity of fungal VOCs [24, 48,49 ], the compounds benzothiazole or terpenes including 1,8-cineole and camphene emitted by $F$. culmorum in soil might played a role in the inhibition of bacterial motility and growth.

Several VOCs produced by the roots of $C$. arenaria or $F$. culmorum were tested in a diffusion assay revealing that VOCs of different classes can disperse over long distance $(>12 \mathrm{~cm})$ in soil. This supports the hypothesis that VOCs can indeed play a significant role in long-distance belowground interactions.

Overall, this study provides novel information on the ecological importance of VOCs in plant-microbe interactions in soil. We demonstrated for the first time that distant soil bacteria can be attracted by plant root VOCs and revealed that plant VOCs emitted under a stress situation represent VOCs initially detected for Carex roots and F. culmorum in soil, respectively. A reliable detection directly at the release point in the central vessel was not possible because of surface saturation on the PDMS tubes

such as fungal infestation can recruit beneficial bacteria from outside the rhizosphere. In contrast to the vast majority of studies on VOC-mediated belowground interactions using very artificial conditions and studying only one-toone interactions (reviewed in [12,13,31]), the olfactometer setting used in this study resembles more closely the natural conditions belowground. Thus, the obtained results can strongly contribute to the understanding of the VOCmediated interactions in an ecosystem context and pinpoint that VOCs [50] are important signals or antimicrobials with potential for application in agriculture.

Acknowledgements We thank Hans Zweers (Netherlands Institute of Ecology) and Peter Coelen (Coelen Glastechniek) for technical assistance.

Author contributions K.S.B. and P.G. contributed to conception and designed experiments. K.S.B. performed all experiments in collaboration with M.H., S.G., and J.M. K.S.B. analyzed and interpreted the 
data as well as created figures and tables. K.S.B. and P.G. drafted the manuscript with contributions from all the co-authors.

Funding This study was financed by the Netherlands Organization for Scientific Research (NWO), VIDI personal grant (864.11.015). This is publication 6403 of the NIOO-KNAW.

\section{Compliance with ethical standards}

Conflict of interest The authors declare that they have no conflict of interest.

\section{References}

1. Robert-Seilaniantz A, Bari R, Jones JDG. A biotic or abiotic stress? In: Pareek A, Sopory SK, Bohnert HJ, editors. Abiotic stress adaptation in plants: physiological, molecular and genomic foundation. Dordrecht, Netherlands: Springer; 2010. p. 103-22.

2. Mendes R, Garbeva P, Raaijmakers JM. The rhizosphere microbiome: significance of plant beneficial, plant pathogenic, and human pathogenic microorganisms. FEMS Microbiol Rev. 2013;37:634-63.

3. Paterson E, Gebbing T, Abel C, Sim A, Telfer G. Rhizodeposition shapes rhizosphere microbial community structure in organic soil. New Phytol. 2007;173:600-10.

4. Philippot L, Raaijmakers JM, Lemanceau P, van der Putten WH. Going back to the roots: the microbial ecology of the rhizosphere. Nat Rev Microbiol. 2013;11:789-99.

5. Rasmann S, Turlings TC. Root signals that mediate mutualistic interactions in the rhizosphere. Curr Opin Plant Biol. 2016;32:62-8.

6. Hartmann T. Plant-derived secondary metabolites as defensive chemicals in herbivorous insects: a case study in chemical ecology. Planta. 2004;219:1-4.

7. Peters NK, Frost JW, Long SR. A plant flavone, luteolin, induces expression of Rhizobium meliloti nodulation genes. Science. 1986;233:977-80.

8. Neal AL, Ahmad S, Gordon-Weeks R, Ton J. Benzoxazinoids in root exudates of maize attract pseudomonas putida to the rhizosphere. PLoS ONE. 2012;7:e35498.

9. Van Dam NM, Weinhold A, Garbeva P. Calling in the dark: the role of volatiles for communication in the rhizosphere. In: Blande JD, Glinwood R, editors. Deciphering chemical language of plant communication. Springer International Publishing Cham; 2016. p. $175-210$.

10. Venturi V, Keel C. Signaling in the rhizosphere. Trends Plant Sci. 2016;21:187-98.

11. Lemfack MC, Nickel J, Dunkel M, Preissner R, Piechulla B. mVOC: a database of microbial volatiles. Nucleic Acids Res. 2014;42:D744-748.

12. Schmidt R, Cordovez V, de Boer W, Raaijmakers J, Garbeva P. Volatile affairs in microbial interactions. ISME J. 2015;9:2329-35.

13. Bitas V, Kim HS, Bennett JW, Kang S. Sniffling on microbes: diverse roles of microbial volatile organic compounds in plant health. Mol Plant-Microbe Interact. 2013;26:835-43.

14. Effmert U, Kalderas J, Warnke R, Piechulla B. Volatile mediated interactions between bacteria and fungi in the soil. J Chem Ecol. 2012;38:665-703.

15. Ahmad A, Viljoen AM, Chenia HY. The impact of plant volatiles on bacterial quorum sensing. Lett Appl Microbiol. 2015;60:8-19.

16. Ali JG, Alborn HT, Stelinski LL. Subterranean herbivore-induced volatiles released by citrus roots upon feeding by Diaprepes abbreviatus recruit entomopathogenic nematodes. J Chem Ecol. 2010;36:361-8.

17. Rasmann S, Köllner TG, Degenhardt J, Hiltpold I, Toepfer S, Kuhlmann U, et al Recruitment of entomopathogenic nematodes by insect-damaged maize roots. Nature. 2005;434:732-7.

18. Van Tol RWHM, Van Der Sommen ATC, Boff MIC, Van Bezooijen J, Sabelis MW, Smits PH. Plants protect their roots by alerting the enemies of grubs. Ecol Lett. 2001;4:292-4.

19. Piesik D, Lemnczyk G, Skoczek A, Lamparski R, Bocianowski J, Kotwica K, et al Fusarium infection in maize: volatile induction of infected and neighboring uninfected plants has the potential to attract a pest cereal leaf beetle, Oulema melanopus. J Plant Physiol. 2011;168:1534-42.

20. Piesik D, Panka D, Delaney KJ, Skoczek A, Lamparski R, Weaver DK. Cereal crop volatile organic compound induction after mechanical injury, beetle herbivory (Oulema spp.), or fungal infection (Fusarium spp.). J Plant Physiol. 2011; 168:878-86.

21. Becker EM, Herrfurth C, Irmisch S, Kollner TG, Feussner I, Karlovsky P, et al Infection of corn ears by Fusarium spp. induces the emission of volatile sesquiterpenes. J Agric Food Chem. 2014;62:5226-36.

22. Henriquez MA, Adam LR, Daayf F. Alteration of secondary metabolites' profiles in potato leaves in response to weakly and highly aggressive isolates of Phytophthora infestans. Plant Physiol Biochem. 2012;57:8-14.

23. Garbeva P, Hordijk C, Gerards S, de Boer W. Volatile-mediated interactions between phylogenetically different soil bacteria. Front Microbiol. 2014;5:289.

24. Schmidt R, Etalo DW, de Jager V, Gerards S, Zweers H, de Boer $\mathrm{W}$, et al. Microbial small talk: volatiles in fungal-bacterial interactions. Front Microbiol. 2016;6:1495.

25. Schulz-Bohm K, Tyc O, de Boer W, Peereboom N, Debets F, Zaagman N, et al Fungus-associated bacteriome in charge of their host behavior. Fungal Genet Biol. 2016;102:38-48.

26. Schulz-Bohm K, Geisen S, Wubs ERJ, Song C, de Boer W, Garbeva P. The prey's scent-volatile organic compound mediated interactions between soil bacteria and their protist predators. ISME J. 2017;11:817-20.

27. Schulz-Bohm K, Zweers H, de Boer W, Garbeva P. A fragrant neighborhood: volatile mediated bacterial interactions in soil. Front Microbiol. 2015;6:1212.

28. Kallenbach M, Veit D, Eilers EJ, Schuman MC. Application of silicone tubing for robust, simple, high-throughput, and timeresolved analysis of plant volatiles in field experiments. BioProtoc. 2015;5:e1391.

29. Song CX, Schmidt R, de Jager V, Krzyzanowska D, Jongedijk E, Cankar K, et al Exploring the genomic traits of fungus-feeding bacterial genus Collimonas. BMC Genom. 2015;16:1103.

30. Xia J, Sinelnikov IV, Han B, and Wishart DS. MetaboAnalyst 3.0making metabolomics more meaningful. Nucleic Acids Res. 2015;43:W251-W257.

31. De Mendiburu F. agricolae: statistical procedures for agricultural research. R package version 1.2-1. 2014. http://CRAN.R-project. org/package $=$ agricolae.

32. Selvaraj G. Flying whispers of inter-kingdom conversation: a complementary perspective of plant and bacterial volatile signals. Plant Microbe Interact. 2015;75:285-310.

33. Ballhorn DJ, Kautz S. How useful are olfactometer experiments in chemical ecology research? Commun Integr Biol. 2013;6:e24787.

34. Smith CM, Khan ZR, Pathak MD. Techniques for evaluating insect resistance in crop plants. CRC press; 1993.

35. Scherm B, Balmas V, Spanu F, Pani G, Delogu G, Pasquali M, et al Fusarium culmorum: causal agent of foot and root rot and head blight on wheat. Mol Plant Pathol. 2013;14:323-41. 
36. Leveau JH, Uroz S, de Boer W. The bacterial genus Collimonas: mycophagy, weathering and other adaptive solutions to life in oligotrophic soil environments. Environ Microbiol. 2010; 12:281-92.

37. Kamilova F, Leveau JHJ, Lugtenberg B. Collimonas fungivorans, an unpredicted in vitro but efficient in vivo biocontrol agent for the suppression of tomato foot and root rot. Environ Microbiol. 2007;9:1597-603.

38. Grady EN, MacDonald J, Liu L, Richman A, Yuan Z-C. Current knowledge and perspectives of Paenibacillus: a review. Microb Cell Fact. 2016;15:203.

39. Jang Y-W, Jung J-Y, Lee I-K, Kang S-Y, Yun B-S. Nonanoic acid, an antifungal compound from Hibiscus syriacus Ggoma. Mycobiology. 2012;40:145-6.

40. Khanam H, Shamsuzzaman. Bioactive benzofuran derivatives: a review. Eur J Med Chem. 2015;97:483-504.

41. Spencer PA, Towers GHN. Restricted occurrence of acetophenone signal compounds. Phytochemistry. 1991;30:2933-7.

42. Utama IMS, Wills RBH, Ben-yehoshua S, Kuek C. In vitro efficacy of plant volatiles for inhibiting the growth of fruit and vegetable decay microorganisms. J Agric Food Chem. 2002;50:6371-7.

43. Curir P, Danieli B, Dolci M, Pasini C, Guglieri L, Sacco M. Reductive detoxification of the acetophenone skeleton of the carnation phytoanticipin by Fusarium oxysporum f.sp dianthi. Plant Pathol. 2000;49:742-7.

44. Cirou A, Raffoux A, Diallo S, Latour X, Dessaux Y, Faure D. Gamma-caprolactone stimulates growth of quorum- quenching Rhodococcus populations in a large-scale hydroponic system for culturing Solanum tuberosum. Res Microbiol. 2011;162:945-50.

45. Kanchiswamy CN, Mainoy M, Maffei ME. Chemical diversity of microbial volatiles and their potential for plant growth and productivity. Front Plant Sci. 2015;6:151.

46. Horiuchi J-i, Prithiviraj B, Bais HP, Kimball BA, Vivanco JM. Soil nematodes mediate positive interactions between legume plants and rhizobium bacteria. Planta. 2005;222:848-57.

47. Schmidt R, de Jager V, Zuhlke D, Wolff C, Bernhardt J, Cankar $\mathrm{K}$, et al Fungal volatile compounds induce production of the secondary metabolite Sodorifen in Serratia plymuthica PRI-2C. Sci Rep-Uk. 2017;7:862.

48. Keri RS, Patil MR, Patil SA, Budagumpi S. A comprehensive review in current developments of benzothiazole-based molecules in medicinal chemistry. Eur J Med Chem. 2015;89:207-51.

49. Ngan LTM, Moon J-K, Kim J-H, Shibamoto T, Ahn Y-J. Growthinhibiting effects of Paeonia lactiflora root steam distillate constituents and structurally related compounds on human intestinal bacteria. World J Microbiol Biotechnol. 2012;28:1575-83.

50. Panpatte DG, Jhala YK, Shelat HN, Vyas RV. Pseudomonas fluorescens: a promising biocontrol agent and PGPR for sustainable agriculture. In: Singh DP, Singh HB, Prabha R, editors. Microbial inoculants in sustainable agricultural productivity: Vol. 1: Research perspectives. New Delhi, India: Springer; 2016. p. $257-70$. 